MARINE MAMMAL SCIENCE, 9(2):138-155 (April 1993)

(C) 1993 by the Society for Marine Mammalogy

\title{
POPULATION STRUCTURE OF THE BOTTLENOSE DOLPHIN (TURSIOPS TRUNCATUS) AS DETERMINED BY RESTRICTION ENDONUCLEASE ANALYSIS OF MITOCHONDRIAL DNA
}

\author{
Thomas E. Dowling \\ Department of Zoology, Arizona State University, \\ Tempe, AZ 85287 \\ WESIEY M. BROWN \\ Department of Biology and Laboratory of Molecular Systematics, \\ Museum of Zoology, University of Michigan, \\ Ann Arbor, MI 48109
}

\begin{abstract}
Restriction fragment length polymorphisms of mitochondrial DNA (mtDNA) were used to test for population subdivision in the bottlenose dolphin (Tursiops truncatus). Atlantic and Pacific dolphin mtDNA samples exhibited distinctly different haplotypes (approximately $7.4 \%$ sequence divergence), indicating a lack of gene exchange. Within the Atlantic Ocean, mtDNA samples from the Gulf of Mexico and the Atlantic Coast were also found to be distinct, with a sequence divergence of approximately $0.6 \%$. The Atlantic Coast-Gulf of Mexico dichotomy is consistent with patterns of genetic variation from other marine and coastal organisms from this region, and supports the hypothesized role of biogeographic events in promoting the divergence of these and other forms. Regional differentiation was identified along the Atlantic Coast, whereas low sequence divergences among haplotypes and consistent haplotype frequencies actoss populations suggested considerable gene exchange among Gulf of Mexico populations. A highly divergent haplotype found in two individuals from two localities in the Gulf of Mexico is best explained by dispersal from either a distinct offshore Gulf stock or an unsampled Atlantic Coast stock. Additional samples are tequired to test for the existence of a distinct offshore race and, if it exists, to identify its distribution and contribution to population structure.
\end{abstract}

Key words: bottlenose dolphin, Tursiops truncatus, mitochondrial DNA, restriction fragment length polymorphism.

The bottlenose dolphin is abundant in tropical and warm temperate areas worldwide and occasionally strays into colder waters as well. Historically, it has 
Table 1. Locality data, tissue type, and sample sizes $(n)$ for this study.

\begin{tabular}{llc}
\hline \multicolumn{1}{c}{ Locality } & \multicolumn{1}{c}{ Tissue } & $n$ \\
\hline Gulfport, MS & blood & 21 \\
Destin, FL & liver & 1 \\
St. Petersburg, FL & blood & 2 \\
Sarasota, FL & liver & $1^{\mathrm{b}}$ \\
Miami, FL & blood & 5 \\
Indian River, FL & liver & 1 \\
Daytona Beach, FL & liver & 1 \\
Cumberland Island, GA & blood & 4 \\
Roanoke Island, NC & liver & 1 \\
Gulf of California, MX & liver & $1^{c}$ \\
Pacific Ocean, N of Australia & liver & 1 \\
& blood & 11 \\
\hline
\end{tabular}

a This locality includes samples from the Mississippi Management area (Gulfport, Mississippi Sound, and Mobile Bay).

b Total DNA was also isolated from blood of this individual and is included in the count above.

c Because of the poor quality of tissue, only total DNA could be isolated from this individual.

base recognizing restriction endonucleases: HinfI, Hin PI, MboI, MspI, RsaI, Sau96I, ScrFI, and TaqI. The resulting fragments were end-labelled with $\alpha^{32} \mathrm{P}$ dNTPs, separated by electrophoresis through agarose $(1.0-1.5 \%)$ and polyacrylamide $(4.0 \%)$ gels, and visualized by autoradiography as described in Dowling et al. (1990). Fragment sizes were determined by their relative electrophoretic mobilities in comparison with fragments of known size (HindIII digested bacteriophage lambda DNA and HaeIII digested bacteriophage $\phi \mathrm{X}$ RF DNA) that were included in each gel. Fragments as small as 50 base pairs (bp) were detected in these analyses.

Blood samples-The small amounts of blood available from live animals (10$20 \mathrm{ml}$ ) made isolation of sufficient quantities of intact circular mtDNA impractical. Therefore, transfer-hybridization was used to visualize cleavage fragment patterns. Total DNAs were prepared by combining a phenol : chloroform extraction protocol (Hillis et al. 1990) with ultracentrifugation (Dowling et al. 1990). We found that numerous phenol extractions failed to produce DNA that could be efficiently digested by restriction endonucleases, but that sufficiently clean DNA was obtained when an ultracentrifugation step was added.

Buffy coats (white cells and platelets; usual volume was $0.5-1.0 \mathrm{ml}$ ) provided by collectors were resuspended in STE $(10 \mathrm{mM} \mathrm{NaCl}, 100 \mathrm{mM}$ EDTA, 10 $\mathrm{mM}$ Tris, $\mathrm{pH} 7.5)$ to a final volume of $4.5 \mathrm{ml}$. Proteinase $\mathrm{K}(0.05 \mathrm{ml}$ from a $20 \mathrm{mg} / \mathrm{ml}$ stock solution, final concentration $100 \mu \mathrm{g} / \mathrm{ml}$ ) and $20 \%$ SDS in water $(0.5 \mathrm{ml}$, final concentration $0.5 \%)$ were added, and the mixture was incubated at $55^{\circ} \mathrm{C}$ for $2 \mathrm{~h}$ to lyse membranes. Following incubation each sample 
was extracted once with an equal volume of phenol (equilibrated with Tris$\mathrm{HCl}, \mathrm{pH} 7.5$ ), followed by extraction with an equal volume of chloroform: isoamyl alcohol (24:1). DNA was precipitated by addition of $1 / 10$ volume 3 $M$ sodium acetate $(\mathrm{pH} 8.0$ ) and 2 volumes of cold $95 \%$ ethanol followed by incubation at $-20^{\circ} \mathrm{C}$ for approximately $16 \mathrm{~h}$. After centrifugation, precipitated DNA was resuspended in $3 \mathrm{ml}$ of TE $(10 \mathrm{mM}$ Tris, $100 \mathrm{mM}$ EDTA, pH 7.5). Ethidium bromide (EB; from a $10 \mathrm{mg} / \mathrm{ml}$ stock solution, final concentration $1 \mathrm{mg} / \mathrm{ml}$ ) and cesium chloride (solid $\mathrm{CsCl}$ to a final density of 1.55 $\mathrm{g} / \mathrm{ml}$ ) were added, and samples transferred to ultracentrifuge tubes. Each tube was filled to the top with a $\mathrm{CsCl}$ stock solution (density of $1.55 \mathrm{~g} / \mathrm{ml}$ ), sealed, and mixed. Tubes were placed in a Beckman 65VTi rotor and centrifuged at $21^{\circ} \mathrm{C}$ for approximately $16 \mathrm{~h}$ at $55,000 \mathrm{rpm}$. Purified total DNA samples were collected by bottom puncture, and $\mathrm{EB}$ and $\mathrm{CsCl}$ removed by extraction with isopropyl alcohol and dialysis as described in Dowling et al. (1990).

Each total DNA sample was characterized with the following restriction endonucleases: Hinf I, Hin PI, MboI, RsaI, ScrFI, and TaqI. Restriction fragments were separated by electrophoresis through $1.0-1.5 \%$ agarose gels. DNA was transferred from the gel to a nylon filter (GeneScreen Plus, NEN) by capillary action as described in Dowling et al. (1990), except that the transfer was performed under alkaline conditions $(0.4 \mathrm{M} \mathrm{NaOH}, 0.6 \mathrm{M} \mathrm{NaCl}$; Reed and Mann 1985). Following transfer, the filter was placed in neutralizing solution $(0.5 \mathrm{M}$ Tris- $\mathrm{HCl}, \mathrm{pH} 7.0,1.0 \mathrm{M} \mathrm{NaCl})$ and then dried in an oven at $65^{\circ} \mathrm{C}$ for $20 \mathrm{~min}$ (Dowling et al. 1990). The dried filter was placed in $10 \mathrm{ml}$ of prehybridization solution ( $2 \times \mathrm{SSC}, 1 \% \mathrm{SDS}, 0.5 \%$ nonfat dry milk) for $2-4 \mathrm{~h}$ at $65^{\circ} \mathrm{C}$ to reduce background contamination, then hybridized in $10 \mathrm{ml}$ of hybridization solution (radioactive DNA-see below, $2 \times \mathrm{SSC}, 1 \% \mathrm{SDS}, 0.5 \%$ nonfat dry milk, $10 \%$ dextran sulfate) at $65^{\circ} \mathrm{C}$ for approximately $18 \mathrm{~h}$. Purified bottlenose dolphin mtDNA (prepared from solid tissue as described above) was used to prepare a radioactive probe to visualize mtDNA restriction fragments. Purity of the probe was essential as even small amounts of contaminating nuclear DNA produced considerable background contamination, some in the form of discrete fragments. The radioactive probe was prepared using the random priming reaction described in Feinberg and Vogelstein (1983), except that all four $\alpha^{32} \mathbf{P}$ dNTPs were used. Following hybridization, nonspecifically bound probe DNA was removed by soaking the filter in a series of wash solutions (twice, each time for five minutes, in $2 \times \mathrm{SSC}, 0.1 \% \mathrm{SDS}$ at $21^{\circ} \mathrm{C}$, and twice, each time for onehalf to one hour, in $0.1 \times \mathrm{SSC}, 0.1 \% \operatorname{SDS}$ at $65^{\circ} \mathrm{C}$ ). The washed filter was blotted dry, wrapped in plastic wrap, and used to expose autoradiographic film (Kodak XAR). Fragment sizes were estimated by comparison with end-labelled fragments of known size (HindIII digested bacteriophage lambda DNA) that were included in each gel. Only restriction fragments larger than approximately $550 \mathrm{bp}$ were included in the analysis.

Statistical analysis-Distinctive restriction fragment patterns for a specific enzyme were identified alphabetically (for purified meDNA) or numerically (for total DNA). Letters/numbers were assigned by order of discovery and do not reflect similarity of patterns. The composite haplotype for each individual rep- 


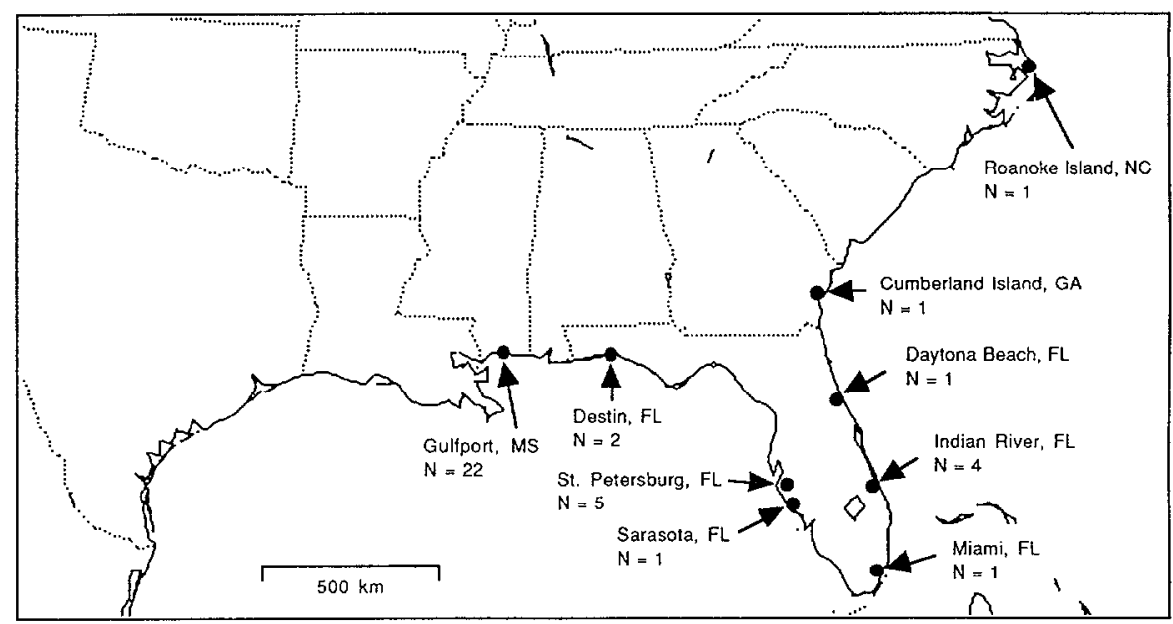

Figure 1. Sample sizes and collection localities for Atlantic bottlenose dolphins. Sample sizes include both total DNA and purified mtDNA samples analyzed (see Table 1 for actual numbers of each kind of sample).

resented fragment patterns for all enzymes, indicated by a string of eight letters for purified mtDNA and six numbers for total DNA.

Frequencies of specific composite haplotypes were used to calculate nucleon diversity $(\hat{b}$, Nei and Tajima 1981). This measure is analogous to average heterozygosity and provides an estimate of the level of mtDNA genotypic diversity within populations. The distribution of variation among populations was quantified using the program HAPLOID (Weir 1990), which uses haplotype frequency data to calculate $\theta$ (analagous to $F_{s f}$ ). Estimates of the mean and standard deviation of $\theta$ were obtained by jackknifing across populations (Weir 1990).

Estimates of sequence divergence among mtDNA haplotypes were calculated from the percentage of shared fragments (Avise et al. 1979). Relationships of haplotypes were obtained from sequence divergence estimates using the unwcighted pair group method (UPGMA, Sneath and Sokal 1974).

\section{Results}

Purified $m t D N A-\mathrm{MtDNA}$ was isolated from solid tissues of 17 individuals from the Pacific and Atlantic Oceans (11 and 6, respectively), including the Gulf of Mexico (Fig. 1, Table 1). Treatment of each sample with the eight restriction enzymes (for one example, see Fig. 2) produced an average of approximately 168 fragments per individual (range $=162-176$ ). The mtDNA molecule was $16,346 \pm 216$ base pairs in length.

Nucleon diversity was high in both oceans, as seven of eleven Pacific and all six Atlantic individuals exhibited different mtDNA haplotypes $(\hat{b}=0.89$ and 1.0 , respectively; see Table 2 for haplotypes). Such high levels of variability are 


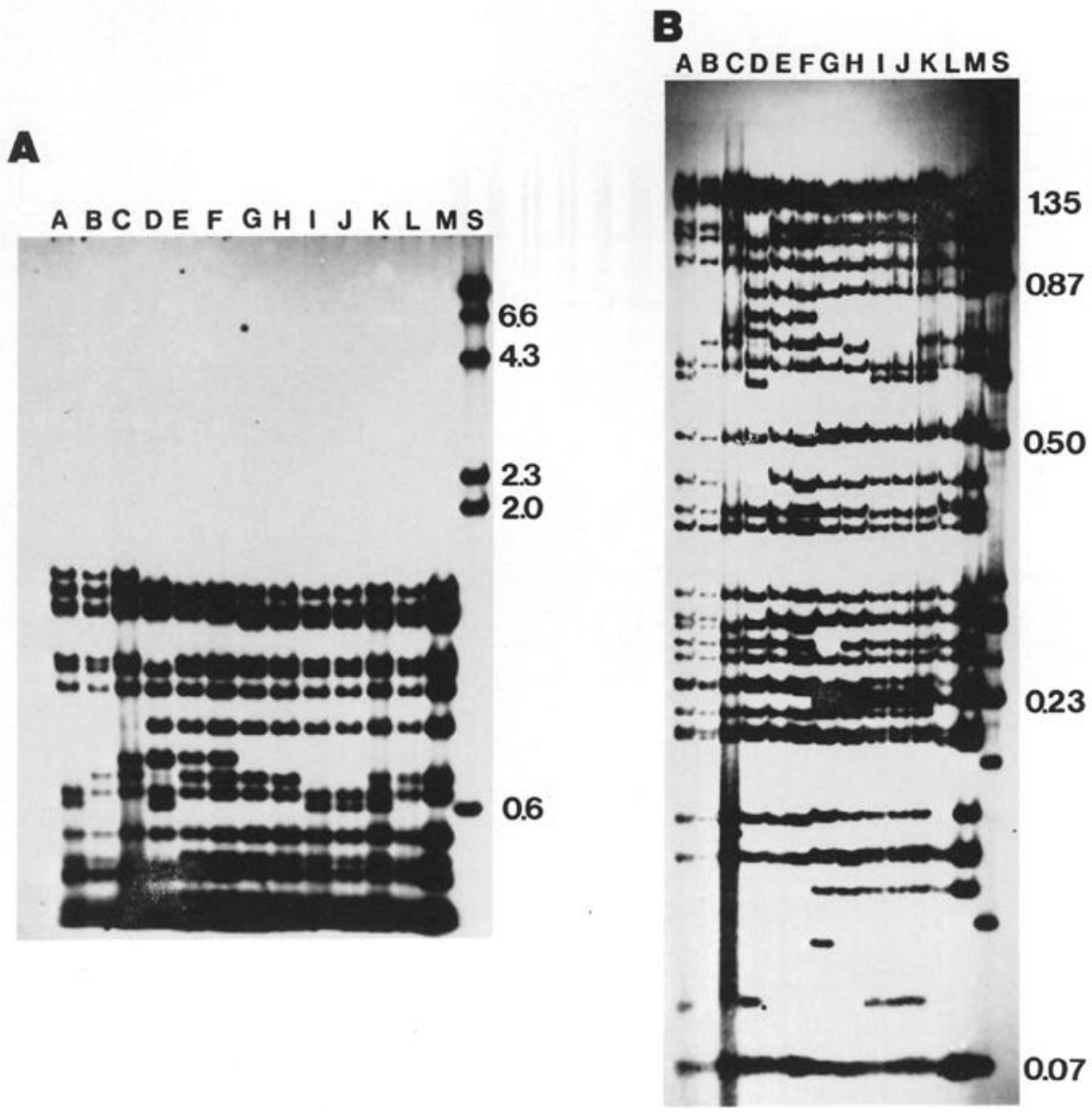

Figure 2. Autoradiogram of bottlenose dolphin mtDNAs digested with the restriction enzyme HinfI. Resulting fragments were end-labelled and separated by electrophoresis through $1.5 \%$ agarose (A) and $4.0 \%$ polyacrylamide (B) slab gels. Samples are identified as follows (see Table 2 for specimen number): A- TT659; B- TT453; C- T1; DT3; E- T4; F- T2; G- TH2; H- TAD; I- TH5; J- TH6; K- CF5; L- TH24; $\mathrm{M}-\mathrm{CF} 3$. S identifies the size standard HindIII digested bacteriophage lambda DNA on A and Hae III digested bacteriophage $\varnothing \mathrm{X} 174 \mathrm{RF}$ DNA on B) with sizes of some of the fragments (in kilobases) to the right.

not surprising. Brown (1980) was able to discriminate each of 21 human mtDNAs with 11 restriction endonucleases, and Avise et al. (1989) reported high nucleon diversity values (range $=0.473-0.998$ ) in a variety of animals, including marine organisms.

Estimates of sequence divergence among the 13 haplotypes ranged from 0.02 to $2.62 \%$ (Table 3 ). Clustering of haplotypes using these distances indicated that the Atlantic and Pacific samples form discrete groups, differing in sequence divergence by approximately $2.4 \%$ (Fig. 3). Samples from the Atlantic and 
Table 2. Composite meDNA haplotypes identified from purified and end-labelled samples. Alphabetical designation is arbitrary and does not reflect the number of fragment differences between haplotypes.

\begin{tabular}{|c|c|c|c|c|c|c|c|c|c|}
\hline Specimen & Locality & Hinf $\mathrm{I}$ & $\operatorname{Hin} \mathrm{PI}$ & $M b o I$ & $M s p \mathrm{I}$ & $R s a \mathrm{I}$ & Sau 96I & Sor FI & TaqI \\
\hline \multicolumn{10}{|c|}{ Gulf of Mexico } \\
\hline TT659 & Gulfport, MS & A & A & A & A & $\Lambda$ & A & A & A \\
\hline TT453 & Destin, FL & B & A & A & A & A & A & A & A \\
\hline $\mathrm{T} 1$ & Sarasota, FL & $\mathrm{C}$ & $A$ & $A$ & A & A & $A$ & B & $A$ \\
\hline \multicolumn{10}{|l|}{ Atlantic Ocean } \\
\hline $\mathrm{T} 2$ & Roanoke Is., NC & $\mathrm{E}$ & C & $\mathrm{D}$ & B & C & $\mathrm{D}$ & A & A \\
\hline T3 & Miami, FL & $\mathrm{D}$ & $\mathrm{B}$ & $\mathrm{B}$ & A & A & $\mathrm{B}$ & A & A \\
\hline $\mathrm{T} 4$ & Daytona Beach, FL & $\mathrm{E}$ & $A$ & C & A & $\mathrm{B}$ & $\mathrm{C}$ & $\mathrm{A}$ & B \\
\hline \multicolumn{10}{|c|}{ Pacific Ocean (from northern Australia) } \\
\hline TAD & $\left(12^{\circ} 27^{\prime} \mathrm{S}, 127^{\circ} 25^{\prime} \mathrm{E}\right)$ & G & $\mathrm{D}$ & F & $\mathrm{C}$ & $\mathrm{H}$ & $\mathrm{F}$ & $\mathrm{C}$ & $\mathrm{C}$ \\
\hline TH2 & $\left(12^{\circ} 18^{\prime} \mathrm{S}, 127^{\circ} 27^{\prime} \mathrm{E}\right)$ & $\mathrm{F}$ & $\mathrm{E}$ & $\mathrm{E}$ & $\mathrm{C}$ & $\mathrm{F}$ & E & $\mathrm{C}$ & $\mathrm{C}$ \\
\hline TH5 & $\left(12^{\circ} 22^{\prime} \mathrm{S}, 127^{\circ} 27^{\prime} \mathrm{E}\right)$ & $\mathrm{H}$ & $\mathrm{E}$ & $G$ & $\mathrm{C}$ & $\mathrm{G}$ & $\mathrm{F}$ & $\mathrm{C}$ & $\mathrm{D}$ \\
\hline TH6 & $\left(12^{\circ} 22^{\prime} \mathrm{S}, 127^{\circ} 27^{\prime} \mathrm{E}\right)$ & $\mathrm{H}$ & $\mathrm{E}$ & G & $\mathrm{E}$ & $\mathrm{E}$ & $\mathrm{F}$ & $\mathrm{C}$ & $\mathrm{D}$ \\
\hline YY2 & $\left(12^{\circ} 24^{\prime} \mathrm{S}, 127^{\circ} 17^{\prime} \mathrm{E}\right)$ & $\mathrm{H}$ & $\mathrm{E}$ & $\mathrm{G}$ & C & $\mathrm{E}$ & F & C & $\mathrm{D}$ \\
\hline CF3 & $\left(12^{\circ} 5 \mathrm{l}^{\prime} \mathrm{S}, 127^{\circ} 00^{\prime} \mathrm{E}\right)$ & $\mathrm{J}$ & $\mathrm{E}$ & G & $\mathrm{D}$ & $\mathrm{D}$ & $\mathrm{F}$ & C & C \\
\hline CF 4 & $\left(12^{\circ} 30^{\prime} \mathrm{S}, 127^{\circ} 14^{\prime} \mathrm{E}\right)$ & $\mathrm{J}$ & $\mathrm{E}$ & $\mathrm{G}$ & $\mathrm{D}$ & D & $\mathrm{F}$ & C & $\mathrm{C}$ \\
\hline CF5 & $\left(12^{\circ} 30^{\prime} \mathrm{S}, 127^{\circ} 26^{\prime} \mathbf{E}\right)$ & $\mathrm{H}$ & $\mathrm{E}$ & G & C & $\mathrm{E}$ & $\mathrm{F}$ & $\mathrm{C}$ & $\mathrm{D}$ \\
\hline CFG & $\left(12^{\circ} 22^{\prime} \mathrm{S}, 126^{\circ} 59^{\prime} \mathrm{E}\right)$ & $\mathrm{H}$ & $\bar{E}$ & $\mathrm{G}$ & C & $\mathrm{E}$ & F & C. & $\mathrm{D}$ \\
\hline CF9 & $\left(13^{\circ} 03^{\prime} \mathrm{S}, 126^{\circ} 12^{\prime} \mathrm{E}\right)$ & J & $\mathrm{E}$ & $\mathrm{G}$ & $\mathrm{D}$ & $\mathrm{D}$ & $\mathrm{F}$ & C & C \\
\hline TH24 & $\left(12^{\circ} 27^{\prime} \mathrm{S}, 127^{\circ} 19^{\prime} \mathrm{E}\right)$ & 1 & $\mathrm{E}$ & G & $\mathrm{D}$ & $\mathrm{D}$ & $\mathrm{F}$ & C & C \\
\hline
\end{tabular}


Table 3. Number of fragments shared (above the diagonal) and sequence divergence (below the diagonal, multiplied by 100) among mtDNA haplotypes identified from purified and end-labelled mtDNA (see Table 2). Number of fragments for each haplotype is presented on the diagonal.

\begin{tabular}{|c|c|c|c|c|c|c|c|c|c|c|c|c|c|}
\hline & TT659 & TT453 & $\mathrm{T} 1$ & $\mathrm{~T} 3$ & $\mathrm{~T} 4$ & $\mathrm{~T} 2$ & $\mathrm{TH} 2$ & TAD & TH5 & TH6 & $\begin{array}{l}\text { YY2 } \\
\text { CF5 } \\
\text { CF6 }\end{array}$ & TH24 & $\begin{array}{l}\mathrm{CF} 3 \\
\mathrm{CF} 4 \\
\mathrm{CF} 9\end{array}$ \\
\hline TT659 & 172 & 172 & 169 & 161 & 159 & 160 & 127 & 126 & 130 & 130 & 131 & 125 & 127 \\
\hline TT453 & 0.02 & 173 & 170 & 159 & 160 & 161 & 128 & 127 & 128 & 128 & 129 & 126 & 128 \\
\hline $\mathrm{T} 1$ & 0.17 & 0.15 & 173 & 159 & 158 & 159 & 128 & 127 & 127 & 127 & 128 & 126 & 128 \\
\hline $\mathrm{T} 3$ & 0.55 & 0.68 & 0.68 & 173 & 155 & 158 & 125 & 126 & 127 & 127 & 128 & 124 & 127 \\
\hline T4 & 0.71 & 0.68 & 0.78 & 0.92 & 174 & 158 & 125 & 126 & 127 & 127 & 128 & 124 & 127 \\
\hline $\mathrm{T} 2$ & 0.70 & 0.67 & 0.78 & 0.81 & 0.86 & 176 & 127 & 127 & 128 & 128 & 129 & 126 & 129 \\
\hline TII2 & 2.42 & 2.38 & 2.38 & 2.63 & 2.61 & 2.53 & 166 & 153 & 157 & 157 & 158 & 156 & 159 \\
\hline TAD & 2.39 & 2.35 & 2.35 & 2.53 & 2.44 & 2.42 & 0.58 & 162 & 156 & 156 & 157 & 156 & 159 \\
\hline TH5 & 2.25 & 2.41 & 2.48 & 2.45 & 2.50 & 2.48 & 0.49 & 0.44 & 167 & 164 & 165 & 155 & 157 \\
\hline TH6 & 2.25 & 2.41 & 2.48 & 2.45 & 2.50 & 2.48 & 0.49 & 0.44 & 0.15 & 167 & 165 & 155 & 157 \\
\hline CF5 & 2.16 & 2.32 & 2.38 & 2.36 & 2.41 & 2.39 & 0.41 & 0.36 & 0.08 & 0.08 & 166 & 156 & 158 \\
\hline TH24 & 2.48 & 2.44 & 2.44 & 2.62 & 2.61 & 2.52 & 0.44 & 0.34 & 0.52 & 0.52 & 0.44 & 163 & 162 \\
\hline CF3 & 2.37 & 2.33 & 2.33 & 2.51 & 2.42 & 2.34 & 0.31 & 0.31 & 0.44 & 0.44 & 0.36 & 0.08 & 164 \\
\hline
\end{tabular}




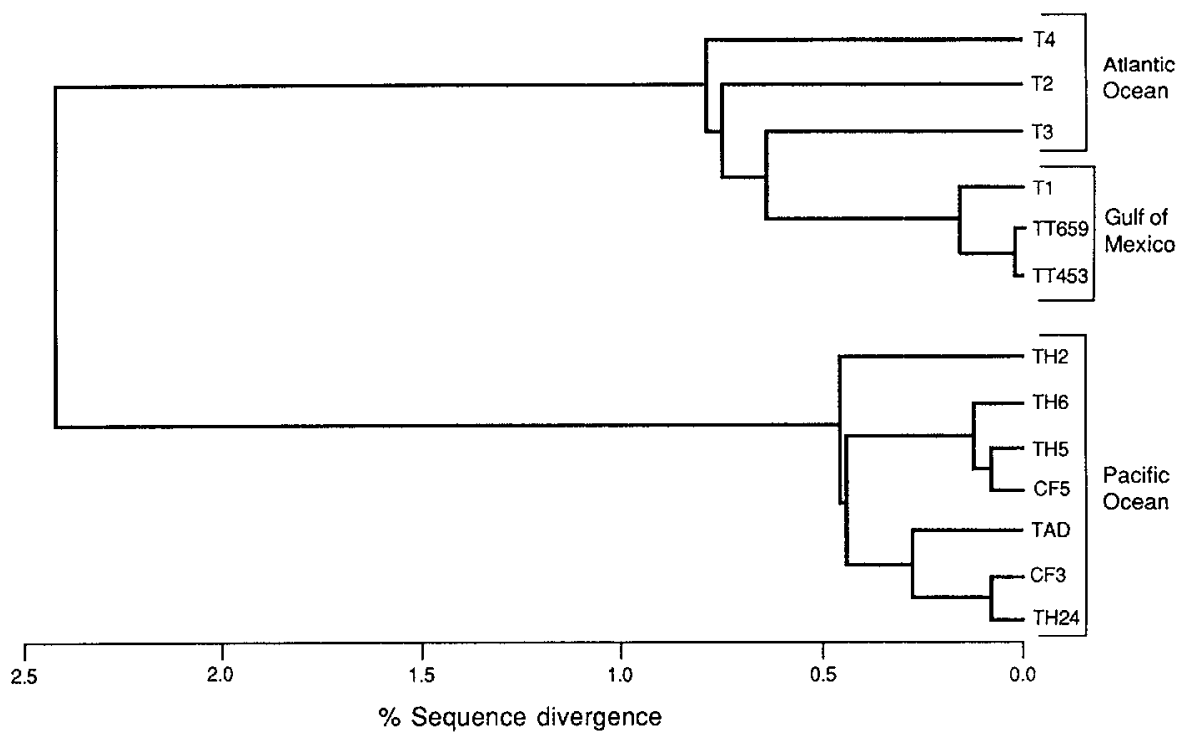

Figure 3. UPGMA phenogram summarizing relationships among meDNA samples analyzed by end-labelling. Sample numbers are provided in Table 2 .

Pacific Oceans were so distinct that no fragment patterns were shared between them.

Levels of divergence within the cluster of haplotypes from the Pacific Ocean range from 0.08 to $0.58 \%$. Within the Atlantic Ocean cluster, the three samples from the Gulf of Mexico (Gulfport, MS; St. Petersburg and Sarasota, FL) form a discrete group $(<0.2 \%$ sequence divergence) relative to the samples from the Atlantic Ocean (Fig. 3). The individual from Miami, FL, had mtDNA most similar to the Gulf of Mexico group (0.64\%). Haplotypes from Roanoke Island, $\mathrm{NC}$, and Daytona Beach, FL, were almost equidistant from the other four Atlantic Ocean haplotypes $(0.82$ and $0.86 \%$, respectively).

Total DNA-Total DNA was isolated from blood and tissues of 35 individuals from the Gulf of Mexico, Atlantic Coast, and the Gulf of California (Fig. 1, Table 1). Digestion of each sample with six restriction endonucleases (for one example, see Fig. 4) identified eight haplotypes (Table 4), each with an average of approximately 54 fragments per individual (range $=53-56$ ).

Results from end-labeling of purified $\mathrm{meDNA}$ and transfer-hybridization of genomic DNA were compared by analysis of a sample (TT453) by both methods (Table 1). This sample provided a reference point for comparison of fragment lengths. Three of the composite haplotypes obtained from genomic DNA samples were identical to those found in samples of purified $\mathrm{mtDNA}(1=$ TT453, 4 $=\mathrm{TT} 659,6=\mathrm{T} 4$ ), demonstrating that the results obtained by transfer-hybridization of total DNA were directly comparable to those obtained by endlabelling purified mtDNA, at least for fragments $\geq 550 \mathrm{bp}$.

Five mtDNA haplotypes were found among the 28 individuals sampled from 
Table 4. Composite mtDNA haplotypes obtained by transfer-hybridization of bottlenose dolphin total DNA. Different fragment patterns are designated by number (1-6) for the following enzymes (in order of occurrence): MboI, RsaI, ScrF I, TaqI, Hinf I, Hin PI. Numerical designation is arbitrary and does not refiect the number of fragment differences between haplotypes.

\begin{tabular}{|c|c|c|c|c|c|c|c|c|c|}
\hline \multirow[b]{2}{*}{ Locality } & \multicolumn{9}{|c|}{ Haplotype } \\
\hline & $\begin{array}{c}1^{\mathrm{a}} \\
111111 \\
\end{array}$ & $\begin{array}{c}2 \\
211111 \\
\end{array}$ & $\begin{array}{c}3 \\
112111 \\
\end{array}$ & $\begin{array}{c}4^{b} \\
111161 \\
\end{array}$ & $\begin{array}{c}5 \\
413231 \\
\end{array}$ & $\begin{array}{c}6^{c} \\
321121 \\
\end{array}$ & $\begin{array}{c}7 \\
531342 \\
\end{array}$ & $\begin{array}{c}8 \\
541152 \\
\end{array}$ & Total \\
\hline \multicolumn{10}{|l|}{ Gulf of Mexico } \\
\hline Gulfport, MS & 13 & 4 & 2 & 2 & 0 & 0 & 0 & 0 & 21 \\
\hline Destin, FL & 1 & 0 & 0 & 0 & 1 & 0 & 0 & 0 & 2 \\
\hline St. Petersburg, FL & 3 & 1 & 0 & 0 & 1 & 0 & 0 & 0 & 5 \\
\hline \multicolumn{10}{|l|}{ Atlantic Ocean } \\
\hline Indian River, FL & 0 & 0 & 0 & 0 & 0 & 4 & 0 & 0 & 4 \\
\hline Cumberland Is., GA & 0 & 0 & 0 & 0 & 0 & 1 & 0 & 0 & 1 \\
\hline \multicolumn{10}{|l|}{ Pacific Ocean } \\
\hline Gulf of California, MX & 0 & 0 & 0 & 0 & 0 & 0 & 1 & 1 & 2 \\
\hline Total & 17 & 5 & 2 & 2 & 2 & 5 & 1 & 1 & 35 \\
\hline
\end{tabular}

a This haplotype is the same as that found in TT453 (Table 2).

b This haplotype is the same as that found in TT659 (Table 2).

c This haplotype is the same as that found in T4 (Table 2). 


\section{$11663322245 \mathrm{~s}$}

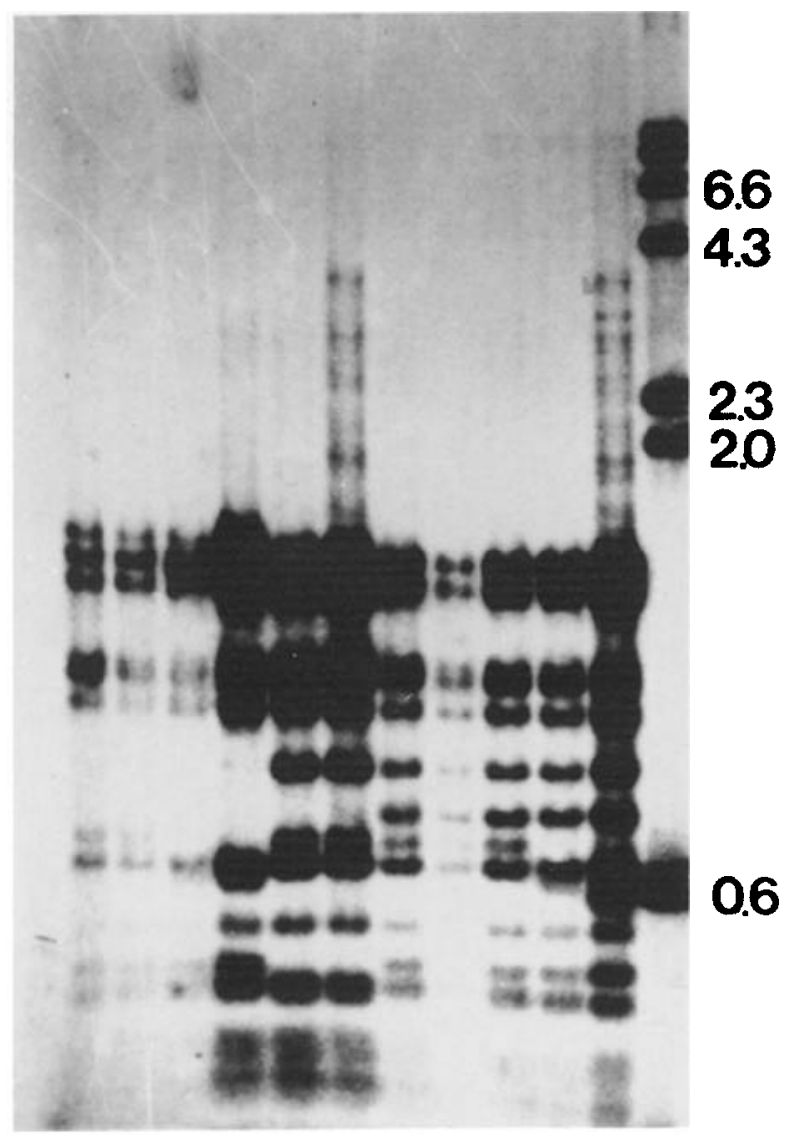

Figure 4. Autoradiogram of bottlenose dolphin mtDNAs digested with the restriction enzyme HinfI. Resulting fragments were separated by electrophoresis through $1.5 \%$ agarose slab gel and visualized by hybridization with radioactively labelled bottlenose dolphin mtDNA (see Materials and Methods for details). Numbers identify HinfI haplotypes (as designated in Table 4). S identifies the size standard (HindIII digested bacteriophage lambda DNA) with sizes of some of the fragments (in kilobases) to the right.

the Gulf of Mexico (Table 4). One of these was found in $61 \%(17 / 28)$ of the individuals. The other four were relatively rare, each occurring at a frequency of less than 20\%. Despite the predominance of one haplotype, considerable nucleon diversity exists in the Gulf of Mexico $(b=0.61)$. Diversity values for the Gulfport and St. Petersburg populations were similar to those for the entire Gulf ( $b=0.60, n=21 ; \hat{b}=0.70 ; n=5$, respectively), while that calculated for the Destin population was higher $(b=1.00 ; n=2)$. The population sample from the Atlantic Coast of Florida (Indian River) showed no diversity $(b=$ $0.00 ; n=4)$. The values for the three Florida populations (Destin, Indian River, 
Table 5. Tests of population subdivision using estimates of $\theta$. Haplotype numbers are identified in Table 4. The jackknife mean $( \pm S D)$ were calculated as described by Weir (1990).

\begin{tabular}{cc}
\hline \hline Haplotype & $\theta$ \\
\hline 1 & -0.204 \\
2 & -0.163 \\
3 & -0.136 \\
4 & -0.136 \\
5 & 0.437 \\
Total & -0.077 \\
\hline
\end{tabular}

Jackknifed over populations: $\theta=0.064 \pm 0.204$.

St. Petersburg) must be regarded as provisional, because of the small sample sizes $(n \leq 5)$.

To test for subdivision among Gulf of Mexico populations, the frequency of haplotypes in each population was used to calculate the $F_{s t}$ analog, $\theta$. Four of the five haplotypes appear to be distributed equally among populations, as indicated by negative values (Table 5). The fifth haplotype (\#5) appeared to be unevenly distributed among populations as indicated by a high $\theta$ value (Table 5). It was found in only two individuals $(2 / 28=\mathrm{ca} .7 \%)$, each from a different locality (St. Petersburg and Destin). It is noteworthy that this haplotype was not found among the large number of individuals from the Gulfport population. Overall, observed haplotypes were evenly distributed among Gulf of Mexico populations, as indicated by the distribution of $\theta$ values $(0.064 \pm 0.204)$ obtained by jackknifing across populations.

Estimates of sequence divergence among the eight haplotypes identified from total DNA samples ranged from $0.24-1.81 \%$ (Table 6). Inspection of the UPGMA results (Fig. 5) indicated that Atlantic haplotypes (Atlantic Coast and Gulf of Mexico) formed a cluster distinct from those in the Pacific (Gulf of California). However, the level of divergence between $A$ tlantic and Pacific clusters was not as large as that observed in the previous comparison involving Atlantic and Pacific populations (Fig. 3). Within the Atlantic Ocean basin most Gulf of Mexico haplotypes form a tight cluster distinct from the Atlantic Coast samples (Indian River, FL, and Cumberland Island, GA), with the exception of haplotype 5 , which is as divergent from the remaining Gulf of Mexico haplotypes ( $1-4)$ as is the Atlantic Coast haplotype (6).

\section{Discussion}

In this study, restriction fragment length polymorphisms among Tursiops truncatus mtDNAs were identified and used to analyze population structure. Comparison of the levels of sequence divergence between mtDNA and total DNA from the same individuals (Fig. 3 versus Fig. 5; T4 $=6$, TT453 $=1$, TT659 = 4) indicated that the use of total DNA provides higher estimates of 
Table 6. Number of fragments shared (above the diagonal) and sequence divergence (below the diagonal, multiplied by 100) among mtDNA haplotypes identified from total DNA (see Table 4). Number of fragments for each haplotype is presented on the diagonal.

\begin{tabular}{cccccccccc}
\hline \hline & 1 & 2 & 3 & 4 & 5 & 6 & 7 & 8 \\
\hline 1 & 54 & 52 & 53 & 53 & 46 & 48 & 46 & 46 \\
2 & 0.24 & 53 & 51 & 51 & 47 & 49 & 47 & 47 \\
3 & 0.16 & 0.40 & 54 & 52 & 46 & 47 & 45 & 45 \\
4 & 0.16 & 0.40 & 0.32 & 54 & 45 & 47 & 47 & 45 \\
5 & 1.27 & 1.01 & 1.27 & 1.46 & 53 & 46 & 44 & 45 \\
6 & 1.14 & 0.89 & 1.32 & 1.32 & 1.43 & 56 & 47 & 47 \\
7 & 1.51 & 1.25 & 1.69 & 1.32 & 1.81 & 1.48 & 56 & 53 \\
8 & 1.51 & 1.25 & 1.69 & 1.69 & 1.62 & 1.48 & 0.46 & 56 \\
\hline
\end{tabular}

divergence for the same haplotypes. This result is an artifact of the method of detection. With the analysis conditions we employed, fragments smaller than $550 \mathrm{bp}$ were detectable by end-labeling, but not by transfer-hybridization. A disproportionate number of these smaller fragments are shared among haplotypes, which results in a lower estimate of divergence when they are included. Because the larger number of fragments analyzed provides a more accurate representation of the mtDNA, comparisons of end-labelled fragments give a more accurate estimate of sequence divergence.

Atlantic versus Pacific comparisons-Analysis of $\mathrm{mtDNA}$ restriction fragment length polymorphisms revealed considerable divergence between the Atlantic
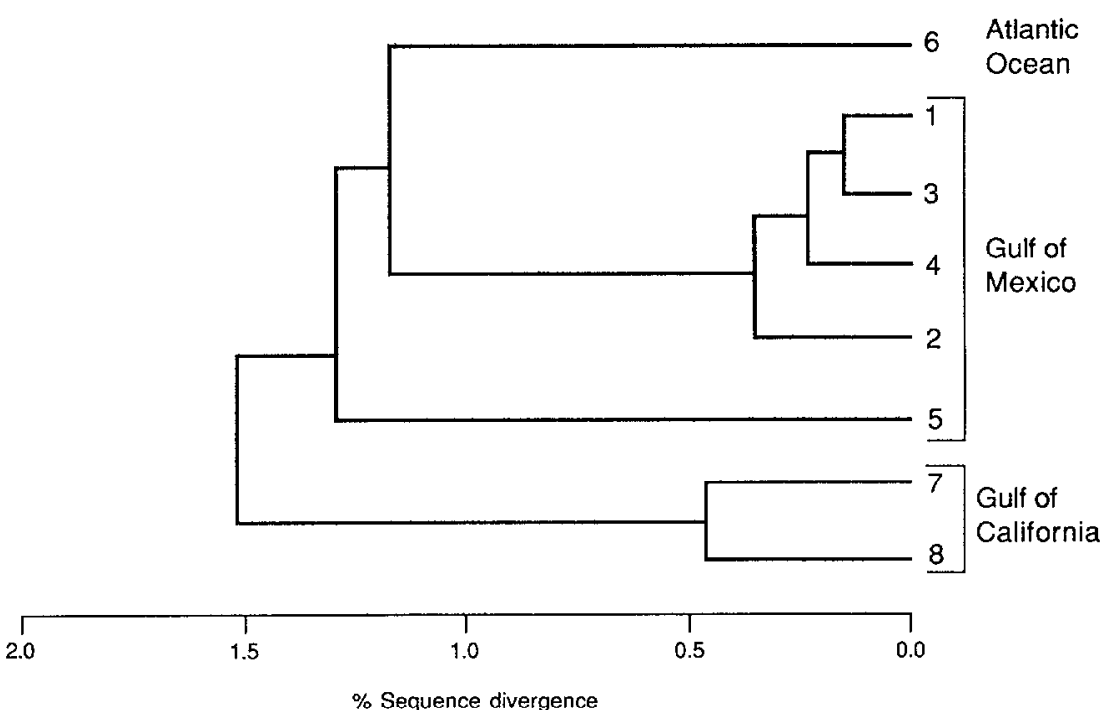

Figure 5. UPGMA phenogram summarizing relationships among mtDNA samples analyzed by transfer-hybridization. Numbers identifying haplotypes as identified in $\mathrm{Ta}$ ble 4 . 
and Pacific population clusters. This result is similar to that found in sea turtles (Bowen and Avise 1989), but differs from studies of skipjack tuna (Graves $e t$ al. 1984).

For the bottlenose dolphin, high mtDNA sequence divergence between oceans $(>2 \%)$ relative to within ocean divergence $(<1 \%)$ suggests a historical disruption of gene flow, with limited interchange between the two oceans. A major barrier to gene flow between these oceans was produced by the emergence of the Panamanian land bridge approximately three million years ago (Marshall $e t$ al. 1982). However, if one applies the "standard" mtDNA clock calibration of $2 \%$ divergence per million years (Wilson et al. 1985) to the average divergence between Atlantic and Pacific Tursiops, their calculated separation occurred approximately 1.25 million years ago. Discordance between the geological and molecular estimates may be explained in three different ways: (1) The Panamanian land bridge may not have been the historical event that isolated these populations. For example, the age estimated from the mtDNA divergence corresponds to a time early in the Pleistocene, possibly implicating changes in sea level associated with glaciation as the factor leading to the isolation of these groups. (2) The date of origin for the Panamanian land bridge may be incorrect, with the emergence being much more recent than is thought. Though a formal possibility, we regard this as highly unlikely. (3) The "standard" rate of evolution, derived from primate mtDNA comparisons, may be inappropriate for Tursiops mtDNA. Relative rates of mtDNA evolution vary among distant (Vawter and Brown 1986) as well as among closely related taxa (DeSalle and Templeton 1988, Dowling and Brown 1989, Smouse et al. 1991).

Gulf of Mexico versus Atlantic Coast comparisons-Levels of divergence between mtDNA haplotypes from the Atlantic Coast and those from the Gulf of Mexico suggest considerable isolation between these regions. These data are generally consistent with genetic data obtained from a variety of coastal organisms previously studied (horseshoe crabs, Saunders et al. 1986; American oyster, Reeb and Avise 1990; seaside sparrow, Avise and Nelson 1989; marine toadfish, Avise et al. 1987b; stone crabs, Bert 1986, Bert and Harrison 1988; sea bass and menhaden, Bowen and Avise 1990). The commonality of patterns across these species has been used to implicate a common set of historical factors, coupled with contemporary restrictions to gene flow (Avise 1992). Reeb and Avise (1990) suggested that changes in water level during the Pleistocene may have created an isolated pocket of suitable habitat in the Gulf of Mexico, and that this isolation has been maintained by existing water current patterns.

In most of the other organisms studied, the point of differentiation between Atlantic and Gulf haplotypes occurs midway up the east coast of Florida. For the bottlenose dolphin, however, the transition point appears to occur further south, near the tip of the Florida peninsula. This shift in position may reflect the way water current patterns impose isolation. For many organisms with pelagic larval phases (like oysters), the current may form a formidable barrier to movement and the distribution of mtDNA variation will closely track overall current patterns. In the case of highly agile organisms, such as bottlenose dolphins, water currents are not likely to physically prevent dispersal. Rather, dolphins 
may be tracking current-entrained food resources (Shane et al. 1986), and, in so doing, incidentally reducing gene exchange between Atlantic and Gulf populations.

Witbin basin comparisons-Small sample sizes prevent population genetic analysis (i.e., calculation of $F$-statistics) of collections from the Atlantic Coast of the United States; however, it is possible to examine population structure by contrasts of within and among population divergences. Levels of divergence among mtDNAs from individuals collected along the Atlantic Coast (from the tip of the Florida peninsula to North Carolina) indicate considerable subdivision among certain regions (Fig. 3). Samples obtained from Florida (Indian River, Daytona Beach) and Georgia (Cumberland Island) were identical (Tables 2 and 4) suggesting relatively recent gene interchange among these locations. However, samples from this general region and two others (from Miami, FL, and Roanoke Island, NC) were distinct from each other (0.8-0.9\% sequence divergence). The high level of divergence among these three sets of Atlantic Coast populations relative to that among populations within the Gulf of Mexico or the Pacific Ocean $(<0.2 \%$ and $<0.5 \%$, respectively) suggests a lack of gene flow among these regions. We considered the possibility that these high divergences might be an artifact induced by the use of tissues from stranded dolphins. MtDNAs from Miami and Roanoke Island were obtained from individuals that had been stranded and died; it is therefore possible that those individuals were not residents at these localities. On the other hand, Sarasota, Cumberland Island, and Daytona Beach mtDNA samples were also isolated from stranded individuals, yet their haplotypes were very similar or identical to those found in known resident animals captured at nearby localities (St. Petersburg and Indian River). Therefore, it seems likely that the relatively high level of sequence divergence among Atlantic Coast populations reflects local variation and not the influence of random stranding of non-resident individuals.

Unlike the Arlantic Coast, analysis of mtDNA from several Gulf of Mexico populations provided only limited evidence of subdivision. Virtually all Gulf individuals possessed highly similar or identical mtDNAs $(<0.2 \%$ from endlabelled samples, $<0.4 \%$ from transfer-hybridization). Analysis of haplotype frequency data also suggested that there was considerable gene flow among populations, as $F$-statistics indicated that most mtDNA haplotypes are distributed evenly among populations. Larger samples from more localities are needed for a more accurate quantification of population subdivision.

The only apparent exception was haplotype 5, which was as divergent as the Atlantic Coast haplotypes from all other Gulf haplotypes. Its high level of sequence divergence from other Gulf haplotypes and its presence at widespread localities suggest that this mtDNA haplotype was likely derived by infrequent invasion of individuals from elsewhere. Haplotype 5 was found in only two females, one collected near Destin, FL, in 1966, and the other captured near St. Petersburg, FL, in 1971 (S. Ridgway, personal communication). Because females disperse less frequently than males (Wells et al. 1980), these individuals are not likely to be closely related (i.e., mother-daughter, sisters, etc.). Therefore, 
the disjunct distribution of this haplotype may be due to separate dispersal events from a distinctive source population.

Previous workers (reviewed in Leatherwood and Reeves 1982) have suggested the existence of distinct onshore and offshore populations of bottlenose dolphin in the Atlantic and Pacific Oceans. Pethaps the unusual haplotype noted above was contributed by individuals from an offshore stock. Alternatively, it may be derived from Atlantic populations not sampled in our survey. The level of divergence of this haplotype from those of the Atlantic Coast and the Gulf of Mexico (Fig. 3 and 5) is consistent with an Atlantic Coast origin. Further sampling is necessary to identify the location of origin for this distinctive haplotype, to test for the existence of a distinct offshore race, and to identify its distribution and contribution to population structure.

The lack of mtDNA divergence among Gulf populations (as indicated by low sequence divergences and consistency of haplotype frequencies across populations) appcars to conflict with previous ecological and behavioral studies of dolphin populations in the Gulf of Mexico. These studies have identified stable, resident populations in which females are highly philopatric and males are more likely to disperse (Wells et al. 1980, Shane et al. 1986). Under these conditions, a rapidly evolving matrilineal marker like mtDNA is expected to identify significant differences among populations. The observed discrepancy is likely not real, as low levels of migration are sufficient to prevent population differentiation (Hartl and Clark 1989). Dolphins are long-lived and, therefore, infrequent exchange among resident groups would be sufficient to prevent differentiation but difficult to detect in typical observational studies.

\section{ACKNOWLEDGMENTS}

Special thanks go to D. K. MacCallum for his assistance in identifying and initiating this project. We would also like to thank A. E. Dizon, L. Hansen, S. H. Ridgway, and G. P. Scott for critical discussion and tissue samples used in this analysis. The manuscript was improved by comments from Ú. Árnason and an anonymous reviewer. Support for this project was provided by the Marine Mammal Commission (postdoctoral fellowship and contract MM3309818-6).

\section{Literature Cited}

Ärnason, Ü., M. Höglund and B. Widegren. 1984. Conservation of highly repetitive DNA in cetaceans. Chromosoma 89:238-242.

Avise, J. C. 1992. Molecular population structure and the biogeographic history of a regional fauna: a case history with lessons for conservation biology. Oikos 61: $62-76$.

Avise, J. C., and R. A. Lansman. 1983. Polymorphism of mitochondrial DNA in populations of higher aninuals. Pages 165-190 in M. Nei and R. K. Koehn, eds. Evolution of genes and proteins. Sinauer Associates, Sunderland, MA.

Avise, J. C., AND W. S. Nelson. 1989. Molecular genetic telationships of the extinct dusky seaside sparrow. Science 243:646-648.

Avise, J. C., R. A. Lansman ANd R. O. Shade. 1979. The use of restriction endonucleases 
to measure mitochondrial DNA sequence relatedness in natural populations. I. Population structure and evolution in the genus Peromyscus. Genetics 92:279-295. Ayise, J. C., J. Arnold, R. M. Ball, E. Bermingham, T. Lamb, J. E. Neigel, C. A. ReEB AND N. C. Saunders. 1987a. Intraspecific phylogeography: The mitochondrial DNA bridge between population genetics and systematics. Annual Review of Ecology and Systematics 18:489-522.

Ayise, J. C., C. A. Reeb and N. C. Saunders. 1987b. Geographic population structure and species differences in mitochondrial DNA of mouthbrooding catfishes (Ariidae) and demersal spawning marinc toadfishes (Batrachoididae). Evolution 41:991-1002.

Avise, J. C., B. W. BoweN AND T. LAMB. 1989. DNA fingerprints from hypervariable mitochondrial genotypes. Molecular Biology and Evolution 6:258-269.

Bfrt, T. M. 1986. Speciation in western Atlantic stone crabs (genus Menippe): the role of geological patterns and climatic events in the formation and distribution of species. Marine Biology 93:157-170.

Bert, T. M., and R. G. Harrison. 1988. Hybridization in western Atlantic stone crabs (genus Menippe): evolutionary history and ecological context influence species interactions. Evolution 42:528-544.

Bowen, B. W., AND J. C. Avise. 1989. An odyssey of the green sea turtle: Ascension Island revisited. Proceedings of the National Academy of Sciences, USA 86:573576.

Bowen, B. W., AND J. C. Avise. 1990. Genetic structure of Atlantic and Gulf of Mexico populations of sea bass, menhaden, and sturgeon: influence of zoogeographic factors and life-history patterns. Marine Biology 107:371-381.

Brown, W. M. 1980. Polymorphism in mitochondrial DNA of humans as revealed by restriction endonuclease analysis. Proceedings of the National Academy of Sciences, USA 77:3605-3609.

Brown, W. M., M. George ANd A. C. Wilson. 1979. Rapid evolution of animal mitochondrial DNA. Proceedings of the National Academy of Sciences, USA 76: 1967-1971.

DAWID, I. B., AND A. W. BlACKLER. 1972. Maternal and cytoplasmic inheritance of mitochondrial DNA in Xenopus. Developmental Biology 29:152-161.

DeSalle, R., and A. R. Templeton. 1988. Founder effects and the rate of mitochondrial DNA evolution in Hawaiian Drosophila. Evolution 42:1076-1084.

Desaile, R., A. R. Templeton, I. Mori, S. Pletscher and J. S. Johnson. 1987. Temporal and spatial heterogeneity of $\mathrm{mtDNA}$ polymorphisms in natural populations of Drosopbila mercatorum. Genetics 116:215-233.

Dowling, T. E., AND W. M. Brown. 1989. Allozymes, mitochondrial DNA, and levels of phylogenetic resolution among four minnow species (Notropis: Cyprinidae). Systematic Zoology 38:126-143.

Dowling, T. E., C. Moritz AND J. D. Palmer. 1990. Nucleic acids II: Restriction site analysis. Pages 250-317 in D. M. Hillis and C. Moritz, eds. Molecular systematics. Sinauer Associates, Sunderland, MA.

Duffield, D. A., AND R. S. Weuss. 1991. The combined application of chromosome, protein and molecular data for the investigation of social unit structure and dynamics in Tursiops truncatus. Reports of the International Whaling Commission (Special Issue 13): 155-169.

Feinberg, A. P., AND B. Vogelstein. 1983. A technique for radiolabelling DNA restriction endonuclease fragments to high specific activity. Analytical Biochemistry 132:6-13.

Graves, J. E., S. D. Ferris and A. E. Dizon. 1984. Close genetic similarity of Atlantic and Pacific skipjack tuna (Katsuwonus pelamis) demonstrated with restriction endonuclease analysis of mitochondrial DNA. Marine Biology 79:315-319.

Grllensten, U., D. Wharton, A. Josefsson and A. C. Wilson. 1991. Paternal inheritance of mitochondrial DNA in mice. Nature 352:255-257. 
Hartu, D., and A. G. Clark. 1989. Population genetics, second edition. Sinauer Associates, Sunderland, MA.

Hillis, D. M., A. Larson, S. K. Davis and E. A. Zimmer. 1990. Nucleic acids III: Sequencing. Pages 318-370 in D. M. Hillis and C. Moritz, eds. Molecular systemarics. Sinauer Associates, Sunderland, MA.

Hoem, W. R., K. H. Blakley and W. M. Brown. 1991. Heteroplasmy suggests limited biparental inheritance of Mytilus mitochondrial DNA. Science 251:14881490 .

Kondo, R. Y. Satta, E. T. Matsuura, H. Ishiwa, N. Takahata and S. I. Chigusa. 1990. Incomplete maternal inheritance transmission of mitochondrial DNA in Drosophila. Genetics 126:657-663

Leatherwood, S., AND R. R. ReEves. 1982. Bottlenose dolphin (Tursiops truncatus) and other toothed cetaceans. Pages 369-414 in J. A. Chapman and G. A. Feldhamer, eds. Wild Mammals of North America. Johns Hopkins University Press, Baltimore, MD.

Marshall, L. G., S. D. Webb, J. J. Sepkoski, Jr. and D. M. Raup. 1982. Mammalian evolution and the Great American Interchange. Science 215:1351-1357.

Moritz, C., T. E. Dowling AND W. M. Brown. 1987. Evolution of animal mitochondrial DNA: relevance for population biology and systematics. Annual Review of Ecology and Systematics 18:269-292.

Ner, M., AND F. TAJIMA. 1981. DNA polymorphism detectable by restriction endonucleases. Genetics 97:145-163.

Reeb, C. A., AND J. C. Avise. 1990. A genetic discontinuity in a continuously distributed species: mitochondrial DN $\Lambda$ in the American oystcr, Crassostrea virginica. Genetics 124:397-406.

ReED, K. C., AND D. A. ManN. 1985. Rapid transfer of DNA from agarose gels to nylon membranes. Nucleic Acids Research 13:7207-7221.

Satta, Y., N. Toyohara, C. Ohtaka, Y. Tatsuno, T. K. Watanabe, E. T. Matsuura, S. I. Chigusa and N. Takahata. 1988. Dubious maternal inheritance of mitochondrial DNA in D. simulans and evolution of D. mauritiana. Genetical Research 52:1-6.

Saunders, N. C., L. G. Kessler And J. C. Avise. 1986. Genetic variation and geographic differentiation in mitochondrial DNA of the horseshoe crab, Limulus polyphemus. Genetics 112:613-627.

Shane, S., R. S. Wells AND B. Würsig. 1986. Ecology, behavior, and social organization of the bottlenose dolphin: a review. Marine Mammal Science 2:34-63.

Smouse, P. E., 'I'. E. Dowling, J. A. Tworek, W. R. Hoen and W. M. Brown. 1991. Effects of intraspecific variation on phylogenetic inference: a likelihood analysis of mtDNA restriction site data in cyprinid fishes. Systematic Zoology 40:393-409.

SNERTH, P. H. A., AND R. R. SOKAL. 1974. Numerical taxonomy. W. H. Freeman Co., San Francisco, CA.

VAWTER, L., AND W. M. BROWN. 1986. Nucleat and mitochondrial DNA comparisons reveal extreme rate variation in the molecular clock. Science 234:194-196.

Wells, R. S., A. B. IRvine and M. D. Scotr. 1980. The social ecology of inshore Odontocetes. Pages 263-317 in L. M. Herman, ed. Cetacean behavior: mechanisms and funcrions. Wiley, NY.

WeIr, B. S. 1990. Genetic data analysis. Sinauer Associates, Sunderland, MA.

Wilson, A. C., R. L. Cann, S. M. Carr, M. George, U. B. Gyllensten, K. M. Helm-Bychowski, R. G. Higuchi, S. R. Palumbi, E. M. Prager, R. D. Sage and M. Stoneking. 1985. Mitochondrial DNA and two perspectives on evolutionary genetics. Biological Journal of the Linnean Society 26:375-400.

Received: March 19, 1992

Accepted: September 21, 1992 